International Journal of Child, Youth and Family Studies (2015) 6(4): 561-580

\title{
EXPLOITATION OR EMPOWERMENT? ADOLESCENT FEMALE DOMESTIC WORKERS IN UGANDA
}

\section{Victoria Flavia Namuggala}

\begin{abstract}
Women's participation in public employment spaces has emerged with new modes of domestic gender hierarchies, especially in the Global South. A new direction in child labor, especially in the domestic sphere, negatively affects female children. Drawing from a larger study that examined the experiences of employers and employees in domestic spaces, this article examines experiences of live-in adolescent female domestic workers, commonly referred to as "house girls", in Kampala, Uganda. Data were collected using qualitative methods that included individual interviews and life stories. Study findings reveal competing narratives pointing to both empowerment and exploitation of house girls. Using a feminist intersectional approach, I focus on gender, age, and location to trace the opportunities, challenges, and agency of the house girls. Using the household as the basic unit of analysis, I foreground the voices of house girls as they tell their lived experiences and survival strategies. My central argument is that domestic workers make a crucial contribution to the effective participation of women working outside the home. I conclude that sustainable empowerment of workers, both domestic and outside the home, hinges upon changes and transformations at the household level.
\end{abstract}

Keywords: house girls, domestic work, domestic workers, intersectionality, empowerment, exploitation

Victoria Flavia Namuggala is a Ph.D. student in the School of Social Transformation at Arizona State University, P.O. Box 876403, 240 E. Orange Mall, Wilson Hall 125, Tempe, Arizona, U.S.A. 85287-6403. She is an Assistant Lecturer in the School of Women and Gender Studies, Makerere University, Kampala, Uganda. E-mail: Victoria.Namuggala@asu.edu 
In examining domestic work in Uganda, this article focuses on adolescent live-in female domestic workers. From a general overview of global trends in domestic wage employment, I narrow down to reflect African regional perspectives, and then concentrate on the specifics of experiences in the private working space of domestic work in Uganda, using the case of Kampala. This background sets the context for the theoretical framework, study design, and methods. Following that is a presentation, discussion, and analysis of findings on house girls' involvement in domestic work, the experiences encountered, and the survival strategies they adopt in these private spaces. In the last section, I present the recommendations and conclusion.

\section{Domestic Work in the Global Context}

Currently there are at least 53 million domestic workers worldwide, 83\% of whom are women (International Labour Organization [ILO], 2013). Tens of millions of women and girls are employed as domestic workers in private households (Negusei, 2013). While such female domestic employees play a crucial role, "[T]hey are among the most exploited and abused workers in the world” (Human Rights Watch, 2010). Experts in transnational labor relations have noted that due to the high unemployment in sending countries, "over 60 million women predominantly from poor countries constitute a mobile labor force especially in the Middle East, Europe, Canada and the United states” (Hawkesworth, 2006, p.14). Adolescent female domestic workers in Uganda, as demonstrated in this article, provide a valid example of domestic workers who have been heavily disadvantaged, exploited, and oppressed. I argue that their subordination is largely anchored in the intersecting position of gender, age, class, and location that adolescent domestic workers occupy.

According to the International Labor Organization's Domestic Workers Convention (ILODWC) No. 189, domestic work is understood as "work performed in or for a household or households". Clause 1.b states that the domestic worker is "any person engaged in domestic work within an employment relationship” (ILO, 2011). The ILO categorizes domestic workers into various groups, including: full-time or part-time; employed by a single household or by multiple households; residing in the household of the employer (live-in worker) or living separately (live-out); and transnational domestic worker or in-country domestic worker. This article focuses on live-in domestic workers in Uganda.

Africa has an estimated 5.2 million domestic workers with a 70\% female composition; however, in a region where "almost everyone has a domestic worker" (ILO, 2013), that estimate is probably low. In sub-Saharan Africa, 65 million children are involved in child labor and among the domestic workers, nine out of ten are girls. In Uganda, about six million people are employed as domestic workers (Platform for Labor Action, 2008). This paper further emphasizes that with the intersection of age and gender for house girls comes increased susceptibility to subordination, exploitation, and oppression, rendering them more liable to verbal and physical abuse, but also to emotional, sexual, and economic manipulation. Uganda has the world's youngest population with over 78\% less than 30 years old (Population Secretariat of Uganda, 2013). In Africa, youth account for 60\% of the unemployed (Ighobor, 2013). Such unemployment has resulted in rural-urban migration (Mukwaya, Bamutaze, Mugarura, \& Benson, 2012) and urban-centered domestic work. 
International Journal of Child, Youth and Family Studies (2015) 6(4): 561-580

\section{Characteristics of Domestic Work in Uganda}

Domestic work in Uganda has many commonalities with domestic labor patterns in the rest of Eastern Africa. However, it also has distinguishing features. While this brief section discusses both common and particular aspects of domestic work in Uganda, I accord special emphasis to the distinguishing features using the case of domestic workers in Kampala. In Uganda (and the rest of Eastern Africa), there has been a mass movement of people from the countryside to urban centers in search of employment since 2002. In 2013, the chairman of the National Planning Authority of Uganda, Wilberforce Kisamba-Mugerwa, noted that while Uganda's population is still 85\% rural, there are signs that rural-urban migration rates are increasing, especially among youth. The job-seekers include many young women who, due to a lack of marketable skills and negative social attitudes towards women working outside the home, find employment in housework, hence the label "house girls". Although the concept of a house girl applies to all female domestic workers irrespective of age, the majority of house girls are young women, most often adolescents below the age of eighteen. The use of "house girls" as a popular term for domestic workers reflects the preponderance of female children in the domestic work sector; however, there are also houseboys. While feminization of labor is not new globally, childhood feminization is more prevalent in the developing world. Domestic work in Uganda follows this pattern.

The increase in the number of domestic workers in Uganda is linked to a number of factors including the increasing number of women in formal employment (Atieno, 2010). This aligns with other global experiences. For instance, the transformation of the economy from manufacturing to service industry in the United States increased women's participation in employment outside the home (Eitzen \& Baca Zinn, 1992). In their examination of domestic work in Britain, Gregson, and Lowe (1994) realized that demand for domestic help emerged primarily from middle-class households with both parents working full-time. Women's increased public involvement provides opportunities but also challenges, such as increased workloads through the "triple shift" (Wallace, 1991) that occurs when public employment is added to the reproductive and community roles women play.

Women have devised strategies to cope with the increase workload, the most outstanding of these being the use of house girls. This seems to be in agreement with Norma Alarcón's (1990) challenge of the binary model of subject formation: whilst referring to cultural settings in which race, gender, and class relations are a central organizing principle of society, Alarcón states that, "one may also become a woman in opposition to other women" (p. 6). Women employed outside the home struggle to become successful by pursuing changes in social constructions that will elevate them to a higher class. Yet, at the same time, they re-inscribe other women (in this study, adolescents) into typical traditional roles, moreover with exploitation, subordination, and poor working conditions. As other feminist scholars have noted, "women can be complicit in the exploitation and oppression of other women” (Fonow \& Cook, 2005, p. 2225). It is thus clear that employment outside the home for women does not necessarily undo the gender division of labor but may rather exacerbate class inequalities and exploitation among women.

Globalization has contributed greatly to labor mobility and commodification of the care economy (Sassen, 2002). This has changed domestic work relations. In Uganda, increased labor 
migration has facilitated the employment of adolescent female youths as live-in domestic workers, due to their lack of other employment skills. Domestic work is enslaving yet at the same time empowering. Some participants termed this double-sided encounter an "indispensable evil". Domestic workers play a crucial role in the success of women employed outside the home by relieving them of domestic chores and providing increased time for formal employment.

While it has been largely regarded as a gender-neutral process, globalization has affected men and women differently by producing "new modes of gender power and disadvantage" (Hawkesworth, 2006, p. 2). For instance, it has resulted in a new form of poverty that is not only feminized but also largely age-specific. Due to the gross human rights abuses involved, domestic work has been referred to by some human rights advocates as a "contemporary form of slavery" (Shahinian, 2010). Despite such connotations, house girls often lack alternative employment, and must rely on domestic work as an important source of income.

This article contributes to knowledge about labor relations in general and specifically about child labor in the domestic sphere, using the case of adolescent live-in domestic workers in Kampala. I analyze how gendered power relations play out between Ugandan female employers and employees in the domestic sphere, while situating this dynamic in the global setting. I assert that domestic workers are "a long-ignored but significant sector of the workforce" (Nisha \& Becker, 2012, p.1). While strategically centering age, I further argue that the household is an important unit influencing socio-economic development and empowerment (especially for women) in Uganda. In analyzing its role in social organization, Tickner (2005) argues that domestic work should not be treated as "a personal, private issue or one to be understood solely in terms of relations between employers and their servants, but one that serves the state's goal of providing the good life for certain class[es] of citizens through oppressing others” (p. 2181). Sustainable economic growth and empowerment for women would thus necessitate transformative change at the household level.

\section{Domestic Help: A Necessity for Women with Families who Work Outside the Home}

The factors discussed in this section are specific to women with children, living in Kampala and working outside the home, who were the focus of the study. The same factors may, however, apply to other categories of women, or even men, who employ house girls. While discussing the factors that create an unceasing demand for house girls, this section draws connections between findings from the present study and related literature.

In Uganda, the maintenance of the family household, especially through "reproductive" roles including child upbringing, cleaning, and food preparation, has over time been the social and cultural responsibility of both the nuclear family and extended relatives including grandparents, siblings, cousins, nephews, and nieces, among others (Kyomuhendo \& McIntosh, 2006). Due to urbanization and the capitalist economy, however, the role of the extended family has changed. Alterations in the social setting have undermined the importance of the extended family, shifting the responsibility of taking care of family members onto the mothers (Aryee, 2005). It is also true that ideologies of motherhood and caring provide a primary argument for domestic work, as Gregson \& Lowe (1994) noted. This is because, in the gender division of labor in Uganda, reproductive roles are largely the responsibility of women, while men go out to the public sphere to earn income. The construction of men as the breadwinners dates back to the colonial period, when men were specifically taken up for wage employment while women 
provided the unpaid domestic labor. As social and economic transformations create places for women to work outside the home, they have not simultaneously transformed the domestic sphere to involve men more actively in domestic roles (Romero, 1992). Women have taken on new employment roles in addition to the traditionally expected roles, which increases the workload to a level that is not easily accommodated. In an analysis of career-pursuing mothers in Kenya, Njung'e (2014) asserts that such women are now away from home for most of the day and relegate the nurturing of their children to domestic helpers. To help maintain their newly achieved positions, women in formal employment employ house girls (Aryee, 2005; Atieno, 2010; Muasya, 2014) to perform domestic chores at minimal pay. Romero (1992), in agreement with other feminist scholars, notes that hiring a female to take over domestic responsibilities from another female is a form of exploitation for economically less-privileged women. Domestic work in Uganda is therefore largely a woman-to-woman phenomenon. Such a system does not challenge the patriarchal nature of society but rather changes the identity of the women involved in this role. It should be noted, however, that this does not rule out the fact that men use domestic workers, and that men and boys also work as domestic workers.

While employment outside the home is in many ways a positive trend for women, this development also has negative consequences (Hawkesworth, 2006). Waylen (1996) suggests for instance that neoliberalism's promotion of free market and anti-state policies have produced "development in reverse for much of the third world" (p.34). Making a specific reference to women, Hawkesworth (2006) further emphasizes that while "development strategies may help expand capitalist markets and foster economic growth, they also heighten the economic responsibilities of individual women, magnifying their burden as providers for family subsistence” (p.14). Haung \& Yeoh (1996), in their study of domestic work in Singapore, observed that public employment for women is "a solution which generates its own sets of injustices and further entrenches gender politics” (p.489). This is also true for Uganda.

Uganda, like many developing countries globally, lacks adequate childcare services and centers, especially in the cities. Many of the upcoming support initiatives are private ventures with little government involvement. This lack of affordable childcare spaces creates a high demand for house girls. Although daycare has advantages, including training children in speech, social etiquette, and physical education, and providing ample space, toys, and time to play, enrollment is very expensive, costing between 500,000 to 700,000 Ugsh per academic school term (three months) ${ }^{1}$. The costs of transportation to and from the center, and of providing basic supplies such as diapers, which are borne by the parent, add to the financial burden. A house girl earns between 20,000 and 50,000 Ugsh per month. As women with children move to working outside the home, the only affordable option for them is to hire another female who has been socialized and trained to take care of children. This explains why few houseboys are employed: they are socially expected not to perform household chores that are considered women's roles.

The use of house girls was more difficult before the improvements in communications technology that make monitoring possible. Women employers noted that they could call home to talk to both the house girl and the children, giving instructions about running the home

\footnotetext{
${ }^{1}$ At the time of the study, the exchange rate for one U.S. dollar was 2,530 Uganda shillings (1 USD: 2530 Ugsh).
} 
International Journal of Child, Youth and Family Studies (2015) 6(4): 561-580

(including what and how to cook) and about giving medication to the children when necessary. Similarly, the house girls used the telephone to contact the employers about issues that would arise during the day, including emergencies. One employer explained:

I don't even know how things would be without these cheap telephone calls. I can load 500 Ugsh and I am set to go for the whole day. I can find out how my boy is doing. Hearing his voice helps me settle at work since I am sure he is doing fine. He is my firstborn ... just made one year last month. As a woman, you know what that means ...

One of the positive developments privatization has brought to Uganda is in communications. Competing telecommunications companies undercut each other's prices, offer promotions such as free calls, and give percentage discounts depending on the time of the call, giving users an opportunity for increased, cost-effective communication. All the households involved in the study had a home phone that could be used to reach the house girl at any time. Improved communication was also noted to have eased interactions with family members and friends in the villages when recruiting house girls. Through the use of services like mobile money ${ }^{2}$ transfer, employers could also send money to people in the villages to facilitate transportation of house girls; house girls would use the same service to send money to their families back home in the villages. These mobile money services have positively impacted communities by bridging the gap between rural and urban settings. Additionally, mobile money minimizes the chances of robbery and petty theft, including pickpocketing, since individuals do not carry cash on hand. Theft and pickpocketing are very common, especially during the festive season, a time when house girls as well as other people travel back home for holidays. These services also save house girls any transportation expenses that would be incurred by travelling to their village to take money back to their dependants. In addition to being relatively cheaper and more conveniently accessible than other forms of money transfer, such as bank accounts, mobile money is fast, and reaching the intended recipients within minutes.

Despite the wide usage, it should be noted that mobile money services are not free of challenges. Lack of proper identification is one major concern noted by the house girls. Uganda has not had a national identity card system until recently, in 2014, when the task to provide nationals with identity cards was launched (State House of Uganda, 2014). Adults use voters' identification cards for purposes of identification. House girls, however, could not be issued with voters' cards since the majority were below the legal age of 18 .

\section{Study Design and Method}

This article is based on a study focusing on full-time live-in domestic workers in Kampala that was conducted out of personal interest in 2012 after encountering several negative media portrayals of house girls. Despite these portrayals, house girls continued to move to Kampala in search of employment, and employers continued to hire them. This ongoing demand for and supply of domestic workers' services suggested that house girls had an important role in

\footnotetext{
${ }^{2}$ Mobile money is a tool that allows individuals to make financial transactions using cell phone technology (Jack \& Suri, 2011).
} 
International Journal of Child, Youth and Family Studies (2015) 6(4): 561-580

the lives of the employers. It is this role that the study intended to explore by asking questions like: Why do adolescents outnumber other age groups engaged in domestic work? What roles do house girls perform in the household? What are their experiences? How is demand for and supply of domestic workers sustained?

\section{Theoretical Framing}

This study was informed by feminist epistemologies that appreciate theorizing from lived experience. The knowledge produced comes from the actual day-to-day experiences of groups of people who have traditionally been excluded from contributing to academic knowledge (Collins, 2000). Such theorizing provides an alternative conceptualization to the dominant view by centering previously neglected experiences and voices, thus moving margins to center (hooks, 1994). House girls’ perspectives have been silenced in the media in favor of those of the employers. This article therefore prioritizes the experiences of house girls more highly. I acknowledge the problems involved in speaking for others (Alcoff, 1991-1992), hence the use of direct quotes from house girls in this article. I also hold that there is no objective social reality about house girls, but rather multiple constructions that are socially based. Perceptions about and experiences of house girls are local, specific, and dependent on the individuals and groups having them. In the study, I apply the understanding that "realities are always under construction by social actors” (Baxter \& Babbie, 2004, p. 298) and thus have multiple standpoints and perspectives that are context-specific (Harding, 1993). The standpoints are not singly identified but are, rather, intersectional (Crenshaw, 1989; McCall, 2005). The intersectionality approach appreciates that race, gender, class, sexuality, age, and location, among other identities, are mutually constitutive and reinforce each other. In this study therefore the simultaneous occurrence of gender, age, and class took precedence given the location of the study and thus formed the basis for understanding the house girls' experiences. An intersectional perspective of reality opposes the single categorical analysis frameworks that would in this case favor one of gender or age or class. Intersectionality also challenges additive models that would in this case analyze gender and age. Analysis largely dependent on gender misses intra-group differences and how various cultural and social contexts, including religion, influence marginalization. Understanding intra-group dynamics of women dominating other women was critical for this study, hence the application of intersectionality as a tool of analysis.

Intersectionality further acknowledges social location and argues, in agreement with standpoint theorists, that the most marginalized have an epistemic privilege over the privileged (Harding, 1993). Collins (2000) uses the example of black domestic workers to demonstrate that their understanding of reality is more objective than their employers' because the domestic workers must understand both their position and their masters' in order to survive. In the case of this study, house girls are the most marginalized, and thus their experiences provide an alternative understanding to the dominant construction and the negative portrayal of domestic work especially in the media. Because house girls embody the "outsider-within" identity (Collins, 1999) within the domestic working space, they conceptualize reality differently from their employers. Following such epistemological grounding, I centered the voices and understanding of the house girls.

\section{Study Population, Sample, and Analysis}

Participants included 30 employers and 30 employees. Employers, women ranging between the ages of 26 and 43, were working outside the home in both formal and informal 
sectors. Formal employment in this study consists of government employees and individuals working in corporate companies and non-governmental organizations. The informal sector comprises the self-employed who are locally referred to as "business women". In both groups of employers, the women worked away from their homes during the day for at least five days a week.

House girls interviewed ranged between 14 and 17 years old. Out of the 30 house girls interviewed, five had left paid domestic work either for marriage or to take other jobs including food vending and tailoring. Although they were not working as house girls at the time of the study, they had previous experience that they were willing to share. The house girls were identified through their employers and the house girls, in turn, led me to the five former house girls through a snowball sampling method (Atkinson \& Flint, 2004). Snowball sampling was necessary because the house girls were hard to make contact with in the private homes where they worked. The interviews lasted between two and four hours since participants continued to perform their chores throughout the interview process. Interviews were conducted during the day between nine o'clock in the morning and four o'clock in the afternoon; this scheduling facilitated a more comfortable environment for sharing information as the employers were not at home. Permission for audio recording of the responses was obtained from the participants. To facilitate total anonymity, no photographs were taken during the research and numbers identified the individual interview responses by house girls. For purposes of presentation, pseudonyms were added and are used throughout this article.

While a friendly environment was created for comfortable knowledge sharing, I would like to note that an accurate production of the actual story of the house girls is not possible because of the choice these participants make about what to share. This is in agreement with Jackson and Mazzei's (2012) statement that “data is partial, incomplete and always being re-told and re-membered ...” (p. 3).

\section{Data Analysis}

The study research questions guided the design and analysis process. I listened to the data several times and organized it by question; however, new themes continued to emerge. These included coping strategies and agency of house girls. These new themes were coded and incorporated into the previous ones. Themes were then grouped into larger categories. Connections and patterns were identified within and among the categories; how they impact each other is shown in this Data Analysis section. The three major themes are: the factors explaining house girls' involvement in domestic work; the experiences they encounter in that working space; and the survival methods they employ. Generalizations are avoided; instead, specific examples and quotes are used.

\section{Factors Explaining Female Adolescent Involvement in Domestic Work}

The factors influencing adolescents' involvement in domestic labor are many. In most cases, the decision to take work as a house girl has little to do with individual preference, but is grounded in ongoing social crises in Uganda, especially in the rural areas. The feminization of domestic work, on the other hand, is socially constructed, especially in the gendered division of domestic labor that places a heavy work burden on women. Heyzer \& Wee (1994) referred to this as the "genderised mode of labour substitution" (p.39). The individuals performing the roles change, but not the system: The inequality continues unchallenged by society since the women 
International Journal of Child, Youth and Family Studies (2015) 6(4): 561-580

involved are in their expected places. As women who are employed outside the home withdraw from domestic roles, they are replaced by lower-class women; social norms remain intact. Besides the demand for domestic help, there are various push and pull factors that draw girls into domestic work.

Poverty is one major motivation for becoming a domestic worker. All the house girls interviewed were from poor rural households where domestic work was regarded as a potential avenue for economic improvement. Their families could not afford education for their children, therefore, most of the girls had only finished the primary education freely provided by the government through the Universal Primary Education program. Girls' limited education is partly a result of the cultural construction that privileges boys. During the interview with Betty, she mentioned that her parents told her to leave school in order to work and send money for her brother's school fees.

Poor performance also exacerbated girls' dropping out of school. Some of the girls mentioned that they were not performing well in school. Following guidance from parents they left school to look for survival alternatives that were less engaging intellectually. Domestic work, which does not require sophisticated training, provided a valid option. In some instances, the girls’ poor academic performance was apparently itself a product of a disadvantaged family background. Fifteen-year-old Nakato, for instance, noted that her poor performance was not because she was less intelligent but because she lived with a stepmother who made her miss school frequently in order to do chores at home. Even on the days she attended school, she had to first carry out so many chores that she arrive late and fatigued for her classes, impairing her concentration and thus her academic performance.

Beyond the family structure, there are other structural factors leading to the use of adolescent domestic labor. Institutional limited acceptance and support for sexually active youth forms a good example. This has resulted in youth having limited access to contraceptives, leading to unwanted pregnancies. With the criminalization of abortion, and the stigma and moral disqualifications attached to it, girls in this position may have no alternative but to drop out of school and work to support their children. Many are below the age of 18 and legally children themselves, though already parents. Since such "child mothers" have no qualifications, domestic labor is often their sole viable option. Child mothers complained of neglect by their children's fathers (some of whom were also adolescents) as well as anger and disappointment from their parents. These factors contributed to the girls' inability to leave domestic work despite experiencing mistreatment and exploitation. The failure on the part of families and government institutions, including hospitals and schools, to provide youth-friendly reproductive health services, has thus played a role in sustaining the supply of domestic workers.

Structural limitations also come into play in the controversies surrounding child labor. One participant in the study, Aida, had been orphaned by AIDS; her situation speaks to the dilemma child labor raises especially in developing countries like Uganda. Bourdillon (2006) realizes that some people justify employing children as "a route to providing orphans with means of livelihood" (p. ix) especially given the high rate of HIV-related deaths. The prevalence of adult HIV in Uganda is 7.2\%; between 1 and 1.2 million children have been orphaned by the epidemic (UNAIDS, 2012). Besides high prevalence of HIV/AIDS (Nolen, 2008), insurgencies 
like civil wars, especially in the northern part of the country (Cheney, 2007; Mulumba \& Namuggala, 2014; Soto, 2009), also account for loss of parents. These orphaned children need to be supported to survive. Aida noted that when her parents died she was stranded with no school fees, protection, or family members willing to help her out. Her involvement in domestic work therefore was a survival strategy. She explains, "I had nothing! Not food or even friends to talk to. Life was so hard ... I was on my way to live on the streets when I was offered domestic work. Even with a stranger, it was good.”

While providing a means of livelihood is a praiseworthy goal, it does not justify the maltreatment female orphan children face working as house girls. When is alleged help really help? And who is helping whom? Based on the narratives shared by participants in this study, I might argue that, on balance, it is the orphans that are helping their employers. Bourdillon (2006) further clarifies that although children are of necessity permitted to work in the African social setting, unregulated domestic work can result in forced and compulsory labor, detrimental to the health and safety of the children. The house girls interviewed in this study expressed overwhelmingly negative experiences, and we might reasonably suppose that unequal power relations would make their experiences more devastating than those of the employers. Such a conclusion, however, does not mean it is easy for the employers. They also reported challenges, which this article does not explore.

Peer pressure: Some children were constrained and lacked alternatives to working as a house girl, but for others, it was their own choice. As in all situations, especially those involving teenagers, peer influence played a role. The house girls reported knowing friends who went into domestic work due to peer influence and the urge to earn money and live in the city. They noted that girls in the village did not understand how hard it is doing domestic work. Jokingly, Namuli mentioned that “... because they see us on Christmas, smartly dressed and smiling, they think it is all good in Kampala. No one tells people in the village what really happens in daily life.” This is the case for migrant workers generally (see Margold, 1995). Returning home accords status that no one is willing to forego by telling the truth of the humiliation and dehumanization they go through. The house girls look forward to the festive season at Christmas, saving money all through the year to go home and enjoy the time with family and friends.

The preceding discussion presents the reasons why house girls participate in domestic work. I now proceed to examine their experiences in the domestic spaces of employment. Despite the variance in factors explaining their involvement in domestic work, house girls underwent relatively similar experiences, many of which involved exploitation and abuse.

\section{House Girls' Experiences in the Domestic Working Space}

House girls' experiences are personal. They cannot, however, in most cases individually decide either to join or even opt out of domestic work. It usually takes family decision-making for a girl to get involved in domestic work and most employers prefer using girls whose families they know. This guards the employer against unfortunate incidents such as neglect of the children in care, and theft. In the identification and hiring processes for domestic work, the idea of "collectivism" in relation to the individual is emphasized (Wane, 2011). African feminists clarify that due to collectivism, the group is given precedence over the individual and, most importantly, decisions made by the community affect the individual (Chilisa, 2012; Nnaemeka, 2004; Wane, 2011). This is because African communities are relational. 
International Journal of Child, Youth and Family Studies (2015) 6(4): 561-580

Mistreatment and Poor Living Conditions: House girls experienced poor living conditions pertaining to basic needs like bedding and food. Trapped in an unequal power relation, the house girls lamented being treated as lesser humans who are not intelligent and lack common sense. They were yelled at and called by vulgar names by some employers. One participant described her bedding:

I sleep down in the sitting room. I have a small old mattress [one inch by demonstration] and a sheet for covering myself. At times it gets so cold that the bed sheet without a blanket is not enough to keep me warm. I was told [by the employer] I would buy myself bed sheets and a blanket from my savings. I have, however, not saved yet to be able to buy them... (Kate, 12/14/2012, Kampala)

While explaining food-related challenges, another house girl had this to say:

I eat a different type of dish from my boss and her children, yet it is me who makes all the dishes. Isn't that funny? Am I not a human being as well? I take beans and posho much of the time while they take matooke [plantain] with fish and meat most of the time. I eat from the verandah [which also serves as the cooking area] as they eat from the sitting room. I then wash the dishes after they have eaten. I don't like that, I feel bad but with no choice (Kutesa, 12/10/2012, Kampala).

It is hard for house girls to speak out on such issues since they are socialized never to spill family secrets to the public. They are taught to refer to their employers as aunties, which is meant to create a sense of family union. The house girls are thus expected to consider themselves part of the family and therefore suffer in silence. Silence has been identified as one of the major factors heightening domestic violence. This explains the constant call for "breaking the silence" (Uganda Women's Network, 2012). Breaking the silence needs to stretch beyond male-to-female violence to include female-to-female violence, especially in domestic spaces.

Spiritual Infringement: Restriction of religious freedom can exacerbate the power imbalances. Many people regard religion as an important aspect of one’s identity, giving perspective and a sense of belonging. Africans have been described as "notoriously religious", with each society having a specific "set of beliefs and practices ...” (Mbiti, 1990, p.3).

Employers forcing house girls to practice another religion amounts to humiliation, domination, disrespect, and failure to appreciate differences. Employers position themselves as all-knowing and assert that their religious beliefs are superior to those of the employees. This facilitates erasure of alternative narratives while emphasizing universalist religious beliefs in the household space. Betty revealed:

We have to go to church every Sunday for a full day to the Pentecostals [locally referred to as “Abalokole”] but I am a Catholic. Aunt/employer does not allow me to go to the Catholic church. She always says a lot of bad things about the Catholic faith and she wants to change [convert] me. She forces me to pray every night in a Pentecostal way ... (12/ 15/2012, Kampala).

Besides attempting to convert house girls, some employers forced them to participate in activities contradicting their religious beliefs. One Muslim house girl had this to say: 
International Journal of Child, Youth and Family Studies (2015) 6(4): 561-580

...as a Muslim, I don't eat pork, leave alone seeing or even touching it. They know that I am a Muslim but they buy it and I am supposed to prepare and cook it for them... At times it's the only sauce available so I go without food... I am only waiting for a chance to get another job and then I leave. It is too much for me. I would handle anything but this is too much! (Shifah, 12/12/2012, Kampala).

She added that her employer did not allow her to put on the Islamic wear (hijab) since she believed that would cause the house girl to sweat a lot, perhaps creating a bad smell.

Sexual Exploitation and Harassment. Sexual exploitation is also largely explained by power imbalances. The case provided by Nakato suggests that she acceded to the sexual relationship. It is important to understand, however, that the unequal power relationship, coercion, limited exposure, and lack of options, contributed to the concession. Many of these young women were coerced into sexual relations and forced to become involved with the male relatives in the household. Nakato (after obtaining assurance of confidentiality) had this to say:

My boss' husband knows her program for the day. He drops her off at [the] office and the older children to school then [he] comes back home without her knowledge. He demands sex from me. I resisted for some time but he threatened to make me lose my job. Uncle [husband] said every house girl does it. He also promised to rent for me a house in case I got pregnant so I accepted, but I know it is bad. (12/15/2012, Kampala)

Nevertheless, some of the girls were willing participants in such liaisons and, in the case of Kisakye, might even have the support of their parents:

When I left home, aunt [sister to her father] told me I could also use this opportunity to find a man from the city since I had reached marriage age. When aunt's [employer] husband came to me, he said he wanted to marry because I was very hard working so I accepted. I treat aunt well because I know it is her husband. This relationship has helped me a lot. I am now treated better and one time aunt wanted to chase me but uncle [employer] defended me. My family knows about the affair... (12/16/2012, Kampala).

Employment Documentation and Specifications. None of the house girls interviewed had a binding contract stating how much they were to earn and the terms of service. As a result, employers could exploit the house girls, especially by paying them less than originally agreed. Employers who broke the agreement often gave such reasons as lack of satisfaction with a house girl's performance, and mishandling of household property like cutlery and glassware. Some house girls were paid as little as 20,000 Ugshs (10\$) per month. Nansamba, who had worked for two years said:

When I came [direct from the village] she said I did not know what to do so she had to take time and train me in urban life. She would therefore give me 20,000shs and after getting impressed with my performance, she was to increase my pay to 40,000shs per month. I have now spent two years and she is paying me 30,000shs. It is really unfair but I have not yet succeeded in getting a new job. I would like to earn more because I also have a child back home to take care of ... (12/ 18/2012, Kampala). 
It is worse for house girls who are relatives to the employers. The house girls noted that relatives are expected to behave as part of the family although they were rarely treated as such; thus they embody the outsider-within identity. House girls who are related to the employers were sometimes paid in kind with used clothing, shoes, and medical care, with no monetary remuneration involved at all. In the absence of binding contracts, house girls work under a lot of pressure, uncertain of what will happen day by day. While the employers complained about abrupt departures by the house girls, the house girls stated that employers do not give any warning at all relating to dismissal, leaving house girls in a constant state of fear of losing their jobs.

Confinement and Restriction of Movement. House girls face challenges on many levels, including personal, family, and communal. At the personal level, domestic workers are generally required to seek permission to move outside of the home compound. Such restrictions however, can extend beyond the compound to the level of not visiting families for years. This is consistent with Becker's (2013) observation that "isolation in private homes leaves [domestic workers] at particular risk of exploitation and violence” (p.2). While most girls said they were only allowed to go home over Christmas (i.e. once a year for a couple of days), one said she had gone up to three years without visiting her family, although she could keep in touch by means of occasional phone calls. Some house girls were refused permission by their employers to attend important family gatherings, including weddings and funerals. Namusoke, who was raised by her grandmother following the loss of her parents to HIV, had this to say:

When my grandmother died, I received a phone call from the village. I also called my boss and talked to her about it. Well, she said sorry but then asked, "What are we going to do with the kids? Now that she has died, you need to work even harder because you have no one to lean on”. I felt bad indeed but she had been keeping all my salary promising to give me a lump sum in December when going for Christmas. I did not have money to go home so I missed my grandmother’s burial (12/22/2012, Kampala).

It is not only unfortunate but also inhuman that such important functions and memories, which can never be replaced, are denied to these young women. In addition to the pain they go through with their employers, the girls may be blamed by their families and communities for failing to be present at family events, as well as for not making monetary contributions while they are working. They may be termed selfish and ill mannered. Restrictions on movement were, however, not entirely blamed on the employers, even though they played a great role. House girls acknowledged that going home meant spending money on transportation and shopping. Nakanwagi who came from Mutukula, on the border of Uganda and Tanzania, noted that a round trip to her home cost 60,000Ugshs (not including food bought on the way), yet she earned only 40,000 Ugshs. Frequent trips home in this case would not be a good idea given the high expectations at home. Postponing home visits enabled maids like Nakanwagi to save some money.

Many of the experiences discussed above relate to the heavy workload. All the house girls complained about the workload, as well as the harsh working conditions. Some girls talked about waking up at five o'clock in the morning, working with no breaks, and staying up past midnight every day. Sixteen-year-old Nakabugo, while taking me through her typical day, had this to say; 
International Journal of Child, Youth and Family Studies (2015) 6(4): 561-580

I do everything! I wake up around 5 a.m. and make breakfast for everyone, I prepare the kids who go to school so that when aunt wakes up they have already had breakfast and [are] ready to go. They leave home at around 7 a.m. When they leave, I start cleaning up the house just in case any visitor comes to find it clean. I then wash the clothes and as they dry I start the lunch preparation so that when the little boy comes back home at 1 p.m, food is ready. I then resort to the dishes, the compound, ironing ...(12/15/2012, Kampala).

\section{Adaptation and Strategies used by the House Girls}

Domestic work presents challenges for both employers and employees. Michel Foucault states that where there is power and oppression, there is inevitably resistance too (Rabinow, 1984). House girls are not merely passive victims. Rather, they stage resistance and persistence for their survival. Anzaldua (1987) described the survival tactics as a "skill that is developed by marginalized people whose well-being is often dependent on the good will of others" (p.38). In this article it refers to the skills house girls develop to resist the oppression they experience. Sandoval (1991) referred to such resistance as “oppositional consciousness”, which is politically effective in challenging dominant power structures and hierarchies. In response to minimal pay, house girls mentioned that they "made a difference" from their bosses in cases where they are sent to the shops or markets to do any grocery shopping. That is, they escalated the prices of goods without the realization of their employers in order to keep the balance for themselves. Accepting intimate relations with employers' relatives, friends, and neighbors is another survival strategy, albeit one that brings with it such risks as exposure to HIV/AIDS and other sexually transmitted diseases.

I have discussed house girls' keeping money with the employer as disadvantageous to them, especially when the money is not repaid. However, when the employer proves trustworthy, it has served as a good strategy for house girls to accumulate larger sums. Such arrangements have enabled some house girls to make investments in their own villages during the Christmas holiday. Nansamba noted that she had bought two pigs in the village, which, after siring some piglets, would be sold to help see to her children's needs. Some former house girls had used such savings to train in practical skills. A girl who learned sewing, for example, could start her own business as a tailor.

\section{Conclusion}

The foregoing discussion highlights ways in which women can turn against each other due to the patriarchal social construction. I have largely discussed a relationship between women differentiated only by socio-economic class and age. Domestic workers and their employers, the majority of whom are women, continually pose challenges for each other, yet each is important for the existence of the other. Domestic work has facilitated a reconstruction of gender hierarchy and power for women working outside the home, and largely disadvantaged domestically employed women. All participants (employers and employees) agreed that domestic work relationships require much patience; for the house girls, they also require sacrifice and determination. 
I observe a need for consciousness raising especially among the house girls. As Hawkesworth noted, it is very difficult as outsiders to raise new issues, shape the agenda, and adopt new alternatives as courses of action. The marginalized themselves need to be given what Collins (1990) referred to as “a self-definition” (p. 224). This can only be done through consciousness raising, especially in regard to their rights as workers. House girls can frame their own agenda through consciousness raising and alliance building with other community members who acknowledge the oppression involved in domestic labor. Domestic work can no longer be treated as a private issue if human rights violations are to be minimized.

Feminist epistemologies assert that marginalized peoples’ perspectives on the world around them are different and superior to those of the dominant group (Collins, 1999). Rosser (1992) adds that people oppressed by class have a more comprehensive view of reality and that the "standpoint of the oppressed comprehends and includes that of the dominant group" (p. 542). House girls' epistemic position as the marginalized provides a uniquely positioned understanding. In addition, a house girl's outsider-within identity gives her a perspective available to no one else (Collins, 1999). It is such knowledge that house girls produce that can foster social change and transformation. For this reason, this article has centered on their experiences as a way of exploring new knowledge on domestic labor relations in Uganda.

Domestic workers have a wide and varying range of concerns, from immediate to longterm. For instance, while some domestic workers wanted to be paid on a monthly basis, others preferred having their money kept for the whole year. While some wanted to be allowed to go home more often, others had no family to which they could return. It would therefore be wrong to force a universalization of the experiences of domestic workers despite their common background of marginalization. Such people have multiple experiences given their different social and historical locations. I have emphasized that the intersection of gender and age for the house girls creates a more challenging experience given the socio-cultural construction in Uganda that marginalizes not only women but also children (Chenney, 2007). Despite this multiple oppression - largely based on gender, but aggravated by age and class - house girls do not restrict themselves to the victim role. They are agentic, having survival tactics that enable them to navigate the exploitative system set up through the household structure. Above all, I agree with other scholars that domestic work sets a new challenge for feminism in examining further the differences incorporated in the category “woman”. Although women's ability to work outside the home is empowering, it has created a new form of inequality that demands immediate attention. It is critical to specify which woman such employment empowers, and the consequences this presents. 
International Journal of Child, Youth and Family Studies (2015) 6(4): 561-580

\section{References}

Alarcón, N. (1990). The theoretical subject(s) of this bridge called my back and Anglo-American feminism. In G. Anzaldua (Ed.). Making face, making soul/haciendo caras: Creative and critical perspectives by feminists of color (pp. 356-369). San Francisco: Aunt Lute Press.

Alcoff, L. (1991-1992). The problem of speaking for others. Cultural Critique, 20, 5-32. doi:10.2307/1354221

Anzaldua, G. (1987). Borderlands/la frontera: The new mestiza. San Francisco: Sprinter/ Aunt Lute Press.

Aryee, S. (2005). The work-family interface in urban sub-Saharan Africa: A theoretical analysis. In S. A. Y. Poelmans (Ed.), Work and family: An international perspective (pp. 261285). Mahwah, NJ: Lawrence Erlbaum Associates, Inc. http://dx.doi.org/10.4324/9781410612601

Atieno, R. (2010). Explaining female labor force participation: The case of Kenya's informal sector and the effect of the economic crisis. Paper presented to the 2010 Annual IAFFE conference, Buenos Aires, Argentina.

Atkinson, R., \& Flint, J. (2004). Snowball sampling. In M. Lewis-Beck, A. Bryman, \& T. Liao (Eds.), The SAGE encyclopedia of social science research methods (Vol. 1; pp. 10431044). Thousand Oaks, CA: Sage Publications. http://dx.doi.org/10.4135/9781412950589.n931

Baxter, L. A., \& Babbie, E. (2004). The basics of communication research. Belmont, CA: Wadsworth.

Becker, J. (2013). Child domestic workers: 'time to protect us'. Retrieved from the Human Rights Watch website: http://www.hrw.org/news/2013/02/26/child-domestic-workerstime-protect-us

Bourdillon, F. C. M. (2006). Child domestic work in Zimbabwe. Harare: Weaver Press.

Cheney, K. (2007). Pillars of the nation: Child citizens and Ugandan national development. Chicago: The University of Chicago Press. http://dx.doi.org/10.7208/chicago/9780226102498.001.0001

Chilisa, B. (2012). Indigeneous research methodologies. Thousand Oaks, CA: Sage Publications, Inc.

Collins, P. H. (1990). Black feminist thought: Knowledge, consciousness, and the politics of empowerment. Boston: Unwin Hyman. http://dx.doi.org/10.4324/9780203900055

Collins, P. H. (1999). Reflections on the outsider within. Journal of Career Development, 26(1) 85-88. http://dx.doi.org/10.1177/089484539902600107

Collins, P. H. (2000). Black feminist thought: Knowledge, consciousness, and the politics of empowerment (2nd ed.). New York and London: Routledge. 
International Journal of Child, Youth and Family Studies (2015) 6(4): 561-580

Crenshaw, K. (1989). Demarginalizing the intersection of race and sex: A black feminist critique of antidiscrimination doctrine, feminist theory, and antiracist politics, University of Chicago Legal Forum, 140, 139-167.

Eitzen, D. S., \& Baca Zinn, M. (1992). Social problems (5th ed.). Boston: Allyn and Bacon.

Fonow, M. M., \& Cook, J. (2005). Feminist methodology: New applications in the academy and public policy. Signs, 30(4), 2211-2236. http://dx.doi.org/10.1086/428417

Gregson, N., \& Lowe, M. (1994). Servicing the middle classes: Class, gender and waged domestic labour in contemporary Britain. London: Routledge. http://dx.doi.org/10.4324/9780203975299

Harding, S. (1993). Rethinking standpoint epistemologies: What is “strong objectivity"? In L. Alcoff \& E. Potter (Eds.), Feminist epistemologies (pp. 49-82). London: Routledge. http://dx.doi.org/10.4324/9780203760093

Haung, S., \& Yeoh, B. A. (1996). Ties that bind: State policy and migrant female domestic helpers in Singapore. Geoforum, 27(4), 479-493. http://dx.doi.org/10.1016/s0016-7185(96)00023-1

Hawkesworth, E. (2006). Globalisation and feminist activisim. New York, Toronto, Oxford: Rowman \& Littlefield Publishers, Inc.

Heyzer, N., \& Wee, V. (1994). Domestic workers in transient overseas employment: Who benefits, who profits? In The trade in domestic workers: Causes, mechanisms and consequences of international migration Vol. 1. Selected papers from a regional policy dialogue on foreign women domestic workers: International migration, employment and national policies, Colombo, Sri Lanka.

hooks, b. (1994). Teaching to transgress: Education as the practice of freedom. New York: Routledge. http://dx.doi.org/10.4324/9780203700280

Human Rights Watch. (2010, April). Dignity overdue: Decent work for domestic workers. Retrieved from http://www.hrw.org/video/2010/04/27/dignity-overdue-decent-work$\underline{\text { domestic-workers }}$

Ighobor, K. (2013). Africa’s youth: A “ticking time bomb” or an opportunity?. Africa Renewal, May,10. Retrieved from http://www.un.org/africarenewal/magazine/may2013/africa\%E2\%80\%99s-youth-\%E2\%80\%9Cticking-time-bomb\%E2\%80\%9D-oropportunity

International Labour Organization (ILO). (2011). C189 - Domestic workers convention, 2011 (No. 189). Retrieved from http://www.ilo.org/dyn/normlex/en/f?p=NORMLEXPUB:12100:0::NO:12100:P12100_I NSTRUMENT_ID:2551460:NO

International Labour Organization (ILO). (2013). Making decent work a reality for domestic workers in Africa [Press release]. Geneva: Author. Retrieved from http://www.ilo.org/addisababa/media-centre/WCMS_213393/lang--en/index.htm 
International Journal of Child, Youth and Family Studies (2015) 6(4): 561-580

Jack, W., \& Suri, T. (2011). Mobile money: The economics of M-PESA (NBER Working Paper No 16721). Cambridge, MA: National Bureau of Economic Research. doi:10.3386/w16721

Jackson, Y. A., \& Mazzei, A. L. (2012). Thinking with theory in qualitative research. London \& NewYork: Routledge. http://dx.doi.org/10.4324/9780203148037

Kisamba-Mugerwa, W. (2013, April). Statement given at the 46th session of the United Nations Commission on Population \& Development. Retrieved from http://www.un.org/en/development/desa/population/pdf/commission/2013/country/Agend a\%20item\%204/Uganda_Item4.pdf

Kyomuhendo, B. G., \& McIntosh, K. M. (2006). Women, work and domestic virtue in Uganda 1900-2003. Oxford: Ohio University Press \& Fountain Publishers.

Margold, A. J. (1995). Narratives of masculinity and transnational migration: Filipino workers in the Middle East. In A. Ong \& G. M. Petelz (Eds.), Bewitching women, pious men: Gender and body politics in Southeast Asia (pp. 274-298). Los Angeles: University of California Press.

Mbiti, J. S. (1990). African religions and philosophies (2nd ed.). Portsmouth, NH: Heinemann.

McCall, L. (2005). The complexity of intersectionality. Signs, 30(3), 1771-1800. doi:10.1086/426800

Muasya, G. (2014). The role of house helps in work-family balance of women employed in the formal sector in Kenya. In Z. Mokomane (Ed.), Work-family interface in sub-Saharan Africa (pp. 149-159). Cham, Switzerland: Springer International Publishing. http://dx.doi.org/10.1007/978-3-319-01237-7

Mukwaya, P., Bamutaze, Y., Mugarura, S., \& Benson, T. (2012). Rural urban transformation in Uganda (Working paper). Prepared for the joint conference of the International Food Policy Research Institute and the University of Ghana, Accra, Ghana. Retrieved from http://www.ifpri.org/sites/default/files/publications/usspwp10.pdf

Mulumba, D., \& Namuggala, V. F. (2014). War experiences and gendered responses to post conflict reintegration: The case of Lira district in northern Uganda. In L. Asuelime \& S. Francis (Eds.), Selected themes in African political studies: Political conflict and stability (pp. 25-38). New York: Springer. http://dx.doi.org/10.1007/978-3-319-06001-9

Negusei, R. (2013, November). Pushing for justice for domestic workers [Online petition]. Retrieved from Change.org website: https://www.change.org/p/rise-up-for-the-peoplestop-abuse-towards-migrant-domestic-workers-worldwide/u/5385425

Nisha, V., \& Becker, J. (2012). World report 2012: A landmark victory for domestic workers. Retrieved from Human Rights Watch website: http://www.hrw.org/world-report2012/world-report-2012-landmark-victory-domestic-workers

Njung'e, C. (2014, May). How well do you know that house help who has taken over your home? Retrieved from the Daily Nation website: http://www.nation.co.ke/news/How-well-doyou-know-that-house-help-/-/1056/2326352/-/ifxy58z/-/index.html 
International Journal of Child, Youth and Family Studies (2015) 6(4): 561-580

Nnaemeka, O. (2004). Nego-feminism: Theorizing, practicing and pruning Africa's way. Signs, 29(2), 357-385. doi:10.1086/378553

Nolen, S. (2008). 28 Stories of AIDS in Africa. New York: Walker and Company.

Platform for Labour Action. (2014). Call to the government of Uganda to realize decent work for domestic workers. http://www.sunrise.ug/business/corporate/201406/call-to-thegovernment-of-uganda-to-realise-decent-work-for-domestic-workers.html

Population Secretariat of Uganda. (2013). The State of Uganda population report 2013. Kampala: Ministry of Finance, Planning and Economic Development. Retrieved from http://countryoffice.unfpa.org/uganda/drive/SUPRE-REPORT-2013lowres.pdf

Rabinow, P. (Ed.). (1984). The Foucault reader. New York: Pantheon Books.

Romero, M. (1992). Maids in the USA. New York: Routledge.

Rosser, V. S. (1992). Are there feminist methodologies appropriate for the natural sciences and do they make a difference? Women's Studies International Forum, 15(5/6), 535-550. doi:10.1016/0277-5395(92)90057-3

Sandoval, C. (1991). U. S. third world feminism: The theory and method of oppositional consciousness in the post modern world. Genders, 10, 1-24.

Sassen, S. (2002). Global cities and survival circuits. In B. A. Ehrenreich \& A. R. Hochschild (Eds.), Global woman: Nannies, maids, and sex workers in the new economy (pp. 254274). New York: Henry Holt.

Shahinian, G. (2010, October). From domestic work to modern day slavery. Report to the United Nations Human Rights Council. Retrieved from http://www.ohchr.org/EN/NewsEvents/Pages/Domesticworkslavery.aspx

Soto, R. (2009). Tall grass: Stories of suffering and peace in northern Uganda. East Lansing, MI: Michigan State University Press.

State House of Uganda. (2014, April). President addresses Ugandans on national identity card exercise [Press release]. Retrieved from http://www.statehouse.go.ug/media/news/2014/04/14/president-addresses-ugandansnational-identity-card-exercise-13th-april-2014

Tickner, J. A. (2005). Gendering a discipline: Some feminist methodological contributions to international relations. Signs, 30(4), 2173-2188. http://dx.doi.org/10.1086/428416

Uganda Women's Network. (2012, November). The 16 days of activism against gender based violence campaign 2012: From peace in the home to peace in the nation; End violence against women. Retrieved from http://www.uwonet.or.ug/2012/11/from-peace-in-thehome-to-peace-in-the-nation-end-violence-against-women/ 
International Journal of Child, Youth and Family Studies (2015) 6(4): 561-580

UNAIDS (2012). Country progress report, Uganda. Retrieved from http://www.unaids.org

Wallace, T. (1991). Barriers to women's development. In T. Wallace \& C. March (Eds.), Changing perceptions. Oxford: Oxfam.

Wane, N. (2011). African indigenous feminist thought: An anti-colonial project. In N. Wane, A. Kempf, \& M. Simmons (Eds.), The Politics of Cultural Knowledge (pp. 7-21).

Rotterdam: Sense Publishers. http://dx.doi.org/10.1007/978-94-6091-481-2

Waylen, G. (1996). Gender in third world politics. Buckingham, UK: Lynne Rienner Pub. 